\title{
"Factors of human capital fictivization: current trends and influence on the processes of reproduction of human capital"
}

\begin{tabular}{|c|c|}
\hline AUTHORS & $\begin{array}{l}\text { Olena Brintseva (D https://orcid.org/0000-0003-2442-3000 } \\
\mathbb{R} \text { http://www.researcherid.com/rid/G-2045-2017 }\end{array}$ \\
\hline ARTICLE INFO & $\begin{array}{l}\text { Olena Brintseva (2018). Factors of human capital fictivization: current trends and } \\
\text { influence on the processes of reproduction of human capital. Social and labour } \\
\text { relations: theory and practice, } 8(2), 35-41 \text {. doi:10.21511/slrtp.8(2).2018.04 }\end{array}$ \\
\hline DOI & http://dx.doi.org/10.21511/slrtp.8(2).2018.04 \\
\hline RELEASED ON & Monday, 04 March 2019 \\
\hline RECEIVED ON & Friday, 02 November 2018 \\
\hline \multirow[t]{2}{*}{ ACCEPTED ON } & Wednesday, 28 November 2018 \\
\hline & 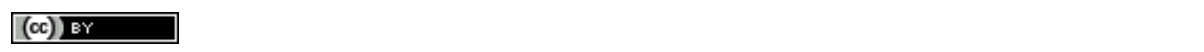 \\
\hline LICENSE & $\begin{array}{l}\text { This work is licensed under a Creative Commons Attribution } 4.0 \text { International } \\
\text { License }\end{array}$ \\
\hline JOURNAL & "Social and labour relations: theory and practice" \\
\hline ISSN PRINT & $2410-4752$ \\
\hline ISSN ONLINE & $2415-3389$ \\
\hline PUBLISHER & LLC "Consulting Publishing Company "Business Perspectives" \\
\hline FOUNDER & $\begin{array}{l}\text { State Higher Educational Establishment "Kyiv National Economic University } \\
\text { named after Vadym Hetman", Social and Labour Relations Institute }\end{array}$ \\
\hline$\sigma^{0}$ & $\begin{array}{l}\text { 三E: } \\
\Xi=\end{array}$ \\
\hline NUMBER OF REFERENCES & NUMBER OF FIGURES \\
\hline 11 & 1 \\
\hline
\end{tabular}

(c) The author(s) 2021. This publication is an open access article. 


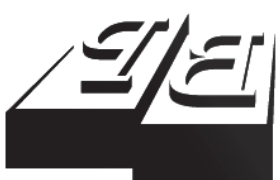

BUSINESS PERSPECTIVES

Publisher:

LLC "CPC "Business Perspectives" Hryhorii Skovoroda lane, 10, 'Sumy, 40022, Ukraine www.businessperspectives.org

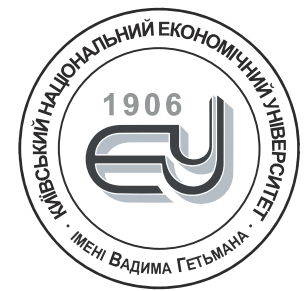

\section{HETMAN KNEU}

Founder:

State Higher Educational Establishment "Kyiv National Economic University named after Vadym Hetman",

Prospect Peremogy, 54/1

Kyiv, 03057, Ukraine

https://kneu.edu.ua/

Received on: 2nd of

November, 2018

Accepted on: 28th of

November, 2018

\section{(c) Olena Brintseva, 2018}

Olena Brintseva, Ph.D. in Economics, Associate Professor Personnel Management and Labor Economics Department, Kyiv National Economic University named after Vadym Hetman, Ukraine.

\section{(c) (i)}

This is an Open Access article, distributed under the terms of the Creative Commons Attribution 4.0 International license, which permit unrestricted re-use, distribution, and reproduction in any medium, provided the original work is properly cited.

\section{FACTORS OF HUMAN CAPITAL FICTIVIZATION: CURRENT TRENDS AND INFLUENCE ON THE PROCESSES OF REPRODUCTION OF HUMAN CAPITAL}

\begin{abstract}
The proliferation of unproductive forms of human capital, deepening of the processes of its digitization, which is currently taking place in the sphere of education, health care and social and labor sphere, is a rather threatening trend for the national economy. In this regard, the purpose of the article is to study the influence of the main factors of the process of the formation of labor potential, the development, use and preservation of human capital in the field of education, health care and social and labor sphere, as well as substantiation of the ways of reducing the negative influence of the factors of digitization. The existing asymmetries in socio-economic development are described, the deepening of which contributes to the spread of unproductive forms of human capital are described by the author. In the educational sphere, it is primarily the reduction of the quality of educational services and corruption; low wages; low level of academic integrity, etc. In the health sector, the processes of filing are primarily due to the poor state of the material base of the national state health care institutions; low wages in state health care institutions; low availability of quality medical services for the general population; insufficient distribution of a culture of health support throughout life, etc. In the social and labor sphere of human capitalization, the following factors contribute to the following: low wages in the whole economy; low social stability, low social guarantees; orientation of entrepreneurs for «fast results», short-term planning; discrimination of certain categories of people in the labor market; low level of social responsibility of the state, etc.
\end{abstract}

Keywords

fictitious human capital, factors of fictivization, education, health care, social and labor sphere

JEL Classification J24, J28, C15, D81

О.Г. Брінцева (Україна)

\section{ЧИННИКИ ФІКТИВІЗАЦІЇ ЛЮДСЬКОГО КАПІТАЛУ: СУЧАСНІ ТЕНДЕНЦІї ТА ВПЛИВ НА ПРОЦЕСИ ВІДТВОРЕННЯ ЛЮДСЬКОГО КАПІТАЛУ}

\section{Анотація}

Поширення непродуктивних форм людського капіталу, поглиблення процесів його фіктивізації, яке нині відбувається в сфері освіти, охорони здоров’я та соціально-трудовій сфері $є$ досить загрозливою тенденцією для національної економіки. У зв’язку з цим метою статті $€$ дослідження впливу основних чинників фіктивізації на процеси формування трудового потенціалу, розвитку, використання та збереження людського капіталу у сфері освіти, охорони здоров'я та соціально-трудовій сфері, а також обгрунтування напрямів зменшення негативного впливу фіктивізаційних чинників. Автором охарактеризовано наявні асиметрії в соціально-економічному розвитку, поглиблення яких сприяє поширенню непродуктивних форм людського капіталу. В освітній сфері це передусім зниження якості освітніх послуг та корупція; низький рівень заробітної плати; низький рівень академічної доброчесності та ін. В сфері охорони здоров'я фіктивізаційні процеси передусім пов'язані 3 поганим станом матеріальної бази вітчизняних державних закладів охорони здоров'я; низьким рівнем заробітної плати в державних установах охорони здоров'я; низьким рівнем доступності якісних медичних послуг для широких верств населення; недостатнім поширенням культури підтримки здоров'я впродовж життя та ін. В соціально-трудовій сфері фіктивізації людського капіталу сприяють: низький рівень оплати праці в цілому по економіці; низька соціальна стабільність, низькі соціальні гарантії; орієнтація підприємців на 
«швидкі результати», короткострокове планування; дискримінація окремих категорій населення на ринку праці; низький рівень соціальної відповідальності держави та ін.

$\begin{array}{ll}\text { Ключові слова } & \begin{array}{l}\text { фіктивний людський капітал, чинники фіктивізації, освіта, охорона здоров’я, } \\ \text { соціально-трудова сфера }\end{array} \\ \text { Класифікація JEL } & \mathrm{J} 24, \mathrm{~J} 28, \mathrm{C} 15, \mathrm{D} 81\end{array}$

\section{ВСТУП}

Формування непродуктивних форм людського капіталу, яке нині відбувається в сфері освіти, охорони здоров'я та соціально-трудовій сфері в цілому є досить загрозливою тенденцією для національної економіки; веде до значних збитків в короткостроковому і довгостроковому періоді; закладає багато суперечностей у подальшу динаміку процесів відтворення людського капіталу; створює нові загрози і виклики в різних сферах суспільного життя, адже наслідки від сформованого нині фіктивного людського капіталу будуть активно проявлятись вже у найближчі роки; крім того вони закладатимуть підгрунтя для подальшого зниження освітнього рівня населення, поширення корупційних схем, деградації моральнодухових цінностей та зниження рівня соціальної відповідальності.

\section{1. ЛІТЕРАТУРНИЙ ОГЛЯА}

Одні з перших робіт, які стали основою сучасної теорії фіктивного людського капіталу були написані Поляковим [8] та Колядіним [4]. Сутність та характерні особливості фіктивного людського капіталу, а також концептуальні підходи та особливості його оцінювання було досліджено в роботах [1, 2]. Розглядаючи проблеми фіктивізації людського капіталу в сучасному дискурсі, варто відзначити, що посилення уваги до дослідження непродуктивних форм людського капіталу, пов'язане не тільки 3 розвитком теорії людського капіталу, а й кризовими явищами в усіх сферах суспільного життя, під впливом яких активізуються фіктивізаційні процеси [3; 7; 9]. Це обумовлює безперечну актуальність дослідження питань фіктивізації на різних етапах відтворення національного людського капіталу.

\section{2. МЕТА ДОСЛІДЖЕННЯ}

Дослідження впливу основних чинників фіктивізації на процеси формування трудового потенціалу, розвитку, використання та збереження людського капіталу у сфері освіти, охорони здоров'я та соціальнотрудовій сфері в цілому, а також обгрунтування напрямів зменшення негативного впливу фіктивізаційних чинників.

\section{3. РЕЗУЛЬТАТИ}

Досліджуючи фіктивізаційні процеси в царині людського капіталу на різних етапах його відтворення, можна класифікувати раніше виокремлені чинники фіктивізації [2] залежно від етапів та сфер відтворення (Таблиця 1). 
Таблиця 1. Чинники фіктивізації людського капіталу в Україні у різних сферах його відтворення

Джерело: Розроблено автором

\begin{tabular}{|c|c|c|c|}
\hline \multirow{2}{*}{$\begin{array}{c}\text { Етапи } \\
\text { відтворення } \\
\text { людського } \\
\text { капіталу }\end{array}$} & \multicolumn{3}{|c|}{ Сфери відтворення людського капіталу } \\
\hline & Сфера освіти & $\begin{array}{c}\text { Сфера охорони } \\
\text { здоров'я }\end{array}$ & $\begin{array}{c}\text { Соціально-трудова } \\
\text { сфера }\end{array}$ \\
\hline $\begin{array}{l}\text { Формування } \\
\text { трудового } \\
\text { потенціалу } \\
\text { / людського } \\
\text { капіталу }\end{array}$ & $\begin{array}{l}\text { - зниження якості освітніх послуг } \\
\text { та корупція, що створюють } \\
\text { передумови для отримання } \\
\text { освітньо-кваліфікаційних рівнів, } \\
\text { не підтверджених реальними } \\
\text { знаннями; } \\
\text { - низький рівень заробітної плати в } \\
\text { освітніх закладах; } \\
\text { - забюрократизованість } \\
\text { вітчизняної освітньої системи; } \\
\text { - низький рівень доступності } \\
\text { якісних освітніх послуг для } \\
\text { населення та ін. }\end{array}$ & $\begin{array}{l}\text { - поганий стан матеріальної бази } \\
\text { вітчизняних державних закладів } \\
\text { охорони здоров'я; } \\
\text { - низький рівень заробітної плати } \\
\text { в державних установах охорони } \\
\text { здоров'я; } \\
\text { - низький рівень доступності якісних } \\
\text { медичних послуг для широких } \\
\text { верств населення та ін. }\end{array}$ & $\begin{array}{l}\text {-низький рівень оплати праці в } \\
\text { цілому по економіці, політика } \\
\text { «дешевої робочої сили»; } \\
\text { - зубожіння працюючого } \\
\text { населення; } \\
\text { - поглиблення «нової } \\
\text { бідності»; } \\
\text { - немає соціальної } \\
\text { стабільності, низькі соціальні } \\
\text { гарантії; } \\
\text { - в більшості роботодавців } \\
\text { немає культури заохочення } \\
\text { народження дітей, підтримки } \\
\text { працюючих жінок з дітьми } \\
\text { та ін. }\end{array}$ \\
\hline $\begin{array}{l}\text { Розвиток } \\
\text { людського } \\
\text { капіталу }\end{array}$ & $\begin{array}{l}\text { - зниження якості освітніх послуг } \\
\text { та корупція, що створюють } \\
\text { передумови для отримання } \\
\text { освітнь-кваліфікаційних рівнів, } \\
\text { не підтверджених реальними } \\
\text { знаннями; } \\
\text { - державні та приватні витрати на } \\
\text { фінансування ВНЗ, які не надають } \\
\text { якісні, конкурентоспроможні } \\
\text { освітні послуги; } \\
\text { - низький рівень заробітної плати в } \\
\text { освітніх закладах; } \\
\text { - низький рівень доступності } \\
\text { якісних освітніх послуг для } \\
\text { населення; } \\
\text { - низький рівень соціальної } \\
\text { відповідальності як науково- } \\
\text { педагогічних працівників, так і } \\
\text { студентів; } \\
\text { - забюрократизованість вітчизняної } \\
\text { освітньої системи; } \\
\text { - інвестиції в фріктивні наукові } \\
\text { дослідження, які майже не } \\
\text { можливо застосувати на практиці } \\
\text { та ін. }\end{array}$ & $\begin{array}{l}\text { - низькі фінансові можливості } \\
\text { населення щодо підтримання } \\
\text { свого здоров'я в належному стані } \\
\text { та інвестування коштів в його } \\
\text { покращення; } \\
\text { - поганий стан матеріальної бази } \\
\text { вітчизняних державних закладів } \\
\text { охорони здоров'я; } \\
\text { - неадекватно високі ціни на послуги } \\
\text { в приватних закладах охорони } \\
\text { здоров'я; } \\
\text { - фрактично немає контролю якості } \\
\text { медичних послуг в приватних } \\
\text { закладах охорони здоров'я; } \\
\text { - низький рівень соціальної } \\
\text { відповідальності працівників } \\
\text { приватних закладів охорони } \\
\text { здоров'я, їх орієнтація передусім } \\
\text { на отримання якомога більших } \\
\text { прибутків, а не на збереження } \\
\text { здоров'я пацієнтів та ін. }\end{array}$ & $\begin{array}{l}\text { - орієнтація підприємців } \\
\text { на «швидкі результати», } \\
\text { короткострокове планування; } \\
\text { - на більшості вітчизняних } \\
\text { підприємств немає культури } \\
\text { інвестування в розвиток } \\
\text { персоналу, планування } \\
\text { внутрішньоорганізаційної } \\
\text { кар'єри та ін. }\end{array}$ \\
\hline $\begin{array}{l}\text { Використан- } \\
\text { ня людського } \\
\text { капіталу }\end{array}$ & $\begin{array}{l}\text { - інвестиції в фіктивні наукові } \\
\text { дослідження, які майже не } \\
\text { можливо застосувати на практиці; } \\
\text { - низький рівень академічної } \\
\text { доброчесності, етики цитування } \\
\text { та публікації наукових праць; } \\
\text { - забюрократизованість } \\
\text { вітчизняної освітньої системи; } \\
\text { - немає культури. навчання } \\
\text { впродовж життя та ін. }\end{array}$ & $\begin{array}{l}\text {-немає культури підтримки здоров'я } \\
\text { впродовж життя, систематичного } \\
\text { проходження профрілактичних } \\
\text { обстежень; } \\
\text { - низькі фрінансові можливості } \\
\text { населення щодо підтримання } \\
\text { свого здоров'я в належному стані } \\
\text { та інвестування коштів в його } \\
\text { покращення; } \\
\text { - поганий стан матеріальної бази } \\
\text { вітчизняних державних закладів } \\
\text { охорони здоров'я; } \\
\text { - неадекватно високі ціни на послуги } \\
\text { в приватних закладах охорони } \\
\text { здоров'я; } \\
\text { - фрактично немає контролю якості } \\
\text { медичних послуг в приватних } \\
\text { закладах охорони здоров'я; } \\
\text { - низький рівень соціальної } \\
\text { відповідальності працівників } \\
\text { приватних закладів охорони здоров'я, } \\
\text { їх орієнтація передусім на отримання } \\
\text { якомога більших прибутків, а не на } \\
\text { збереження здоров'я пацієнтів та ін. }\end{array}$ & $\begin{array}{l}\text { - дискримінація окремих } \\
\text { категорій населення на ринку } \\
\text { праці; } \\
\text { - низький рівень оплати праці; } \\
\text { - фрактична відсутність } \\
\text { соціальних ліфтів; } \\
\text { - кар'єрне просування не за } \\
\text { здібностями, а за зв'язками; } \\
\text { - складна ситуація на ринку } \\
\text { праці, асиметрії в соціально- } \\
\text { трудовій сфері, які сприяють } \\
\text { зростанню непродуктивних } \\
\text { форм людського капіталу } \\
\text { та ін. }\end{array}$ \\
\hline
\end{tabular}


Таблиця 1. Чинники фіктивізації людського капіталу в Україні у різних сферах його відтворення (продовження)

\begin{tabular}{|c|c|c|c|}
\hline $\begin{array}{l}\text { Збереження } \\
\text { людського } \\
\text { капіталу }\end{array}$ & $\begin{array}{l}\text {-низька доступність освіти для } \\
\text { населення старших вікових груп; } \\
\text {-немає культури навчання } \\
\text { впродовж життя та ін. }\end{array}$ & $\begin{array}{l}\text { - низькі фрінансові можливості, } \\
\text { особливо населення старшого віку } \\
\text { що-до підтримання свого здоров'я } \\
\text { в належному стані та інвестування } \\
\text { коштів в його покращення; } \\
\text { - поганий стан матеріальної бази } \\
\text { вітчизняних державних закладів } \\
\text { охорони здоров'я; } \\
\text { - неадекватно високі ціни на послуги } \\
\text { в при-ватних закладах охорони } \\
\text { здоров'я; } \\
\text { - фрактично немає контролю якості } \\
\text { медичних послуг в приватних } \\
\text { закладах охорони здоров'я; } \\
\text { - низький рівень соціальної } \\
\text { відповідальності працівників } \\
\text { приватних закладів охорони } \\
\text { здоров'я, їх орієнтація передусім } \\
\text { на отримання якомога більших } \\
\text { прибутків, а не на збереження } \\
\text { здоров'я пацієнтів та ін. }\end{array}$ & $\begin{array}{l}\text { - асиметрії у пенсійному } \\
\text { законодавстві, значна } \\
\text { диференціація між розміром } \\
\text { отримуваних пенсій; } \\
\text { - дискримінація за віком на } \\
\text { вітчизняному ринку праці; } \\
\text { - низький рівень соціальної } \\
\text { відповідальності держави } \\
\text { та ін. }\end{array}$ \\
\hline
\end{tabular}

Фіктивізаційні процеси найбільш динамічно відбуваються в сфері освіти, охорони здоров’я. Ситуація в соціально-трудовій сфері в цілому також характеризується багатьма проблемами і суперечностями, негативний вплив яких потребує мінімізації вже в найближчій перспективі.

На етапі формування трудового потенціалу ефективність процесів відтворення значною мірою визначається якістю надання освітніх та медичних послуг, їх доступністю для широких верств населення, а також рівнем життя. Саме сформований на цьому етапі трудовий потенціал в майбутньому повинен набути корисного використання і вже розглядатись як національний людський капітал. В питаннях формування як трудового потенціалу, так і розвитку, використання та збереження людського капіталу триєдина система «освіта-охорона здоров'я-соціально-трудова сфера» має розглядатись саме в єдності всіх трьох елементів, адже соціально-трудова сфера забезпечує продуктивне використання та фінансові ресурси для процесів відтворення людського капіталу, освітня система - процеси передачі знань з покоління в покоління, формування інтелектуальної компоненти суспільства, а система охорони здоров’я - підтримання здоров’я та працездатності на належному рівні; iї важливість обумовлена самою природою людини. Однак, на різних етапах відтворення людського капіталу відбуваються фіктивізаційні процеси різної інтенсивності, які зумовлюють різноманітні деформації, виникнення і поширення його непродуктивних форм.

Фіктивізаційні процеси в сфері освіти пов'язані передусім зі зниженням якості освітніх послуг та корупцією, що створюють передумови для отримання освітньо-кваліфікаційних рівнів, не підтверджених реальними знаннями; низьким рівнем заробітної плати в освітніх закладах; забюрократизованістю вітчизняної освітньої системи; низьким рівнем доступності якісних освітніх послуг для населення та ін.

Фіктивізаційні процеси різної інтенсивності в освітній сфері, свідками яких ми стали нині мають різне «обличчя», але в кінцевому підсумку результат один - фіктивний диплом про середню або вищу освіту та збитки для національної економіки від діяльності носіїв фіктивного людського капіталу. Щодо вищої освіти, варто відзначити, що механізм отримання фіктивного диплому може бути різним:

1. людина, «вступивши до вищого навчального закладу (ВН3)» наступні 5-6 років «чекає диплом» не з'являючись на заняття, а інколи навіть на іспити. Це найбільш відверта і ганебна форма фіктивізації людського капіталу в сфері освіти. Яскравими прикладами є події у кількох вітчизняних ВН3, які досить докладно висвітлені в засобах масової інформації [5];

2. людина «навчаючись» у ВНЗ отримує оцінки, які не відповідають фактичному рівню її знань, при цьому використовуючи різні нечесні шляхи отримання вищих балів, порушуючи принципи 
академічної доброчесності;

3. людина, навчаючись у ВНЗ, отримує застарілі знання, які не відповідають вимогам роботодавців та реаліям сьогодення («студенти ніби навчаються, викладачі ніби вчать»). Цей шлях фіктивізації людського капіталу в освітній сфері є одним з найбільш загрозливих як для національної системи освіти, так і для суспільства в цілому. Адже загальне зниження рівня знань випускників ВН3, їх неадаптованість до вимог ринку праці та вимог роботодавців сприяють зростанню молодіжного безробіття, поглибленню кризових явищ в економіці.

Суб’єктами, які беруть участь у фіктивізаційних процесах, що відбуваються в сфері вищої освіти є: споживачі освітніх послуг, ВН3, Міністерство освіти і науки України та інші органи державної влади, які відповідають за якість освітніх послуг в Україні. Слабкість інститутів, які діють в сфері освіти, надмірна бюрократизованість їх діяльності, значні асиметрії, корупція та інші проблемні питання створюють передумови для фіктивізації людського капіталу.

Ситуація в сфері охорони здоров’я також є складною. Фіктивізаційні процеси в цій царині передусім пов'язані з поганим станом матеріальної бази вітчизняних державних закладів охорони здоров'я; низьким рівнем заробітної плати в державних установах охорони здоров’я; низьким рівнем доступності якісних медичних послуг для населення та ін. Значно нижча, ніж в розвинених європейських країнах середня очікувана тривалість життя є інтегральним показником, який відображає безліч проблем сучасного українського суспільства, досить болючою з яких є стан системи охорони здоров'я. Безумовно, впровадження електронної охорони здоров’я - реєстру пацієнтів, лікарів, медичних закладів, які визначено Міністерством охорони здоров’я України [6] в пріоритетах медичної реформи, є важливим напрямом зменшення фіктивізаційних процесів в сфері охорони здоров'я, однак нині заклади охорони здоров’я передусім потребують належного фінансування, системного процесу реформування, який базується на зарубіжному досвіді, але все ж таки адекватно враховує вітчизняні реалії.

Соціально-трудова сфера забезпечує фінансові ресурси для процесів відтворення людського капіталу. 3 огляду на це, до найбільш загрозливих чинників фіктивізації варто віднести: низький рівень оплати праці в цілому по економіці, політика «дешевої робочої сили»; зубожіння працюючого населення; поглиблення «нової бідності»; соціально-економічну та політичну нестабільність, низькі соціальні гарантії, а також низький рівень соціальної відповідальності роботодавців, яскравими прикладами якого $є$ те, що в більшості з них немає культури заохочення людського та професійного розвитку, народження дітей, підтримки працюючих жінок з дітьми та ін.

На етапі розвитку людського капіталу фіктивізаційні процеси в сфері освіти пов'язані з впливом таких чинників: зниження якості освітніх послуг та корупція, що створюють передумови для отримання освітньо-кваліфікаційних рівнів, не підтверджених реальними знаннями; зростання державних та приватних витрат на фінансування ВН3, які не надають якісні, конкурентоспроможні освітні послуги; низький рівень заробітної плати в державних освітніх закладах; низький рівень доступності платних освітніх послуг для населення; низький рівень соціальної відповідальності як науково-педагогічних працівників, так і студентів; забюрократизованість вітчизняної освітньої системи; інвестиції в фіктивні наукові дослідження, які майже не можливо застосувати на практиці та ін.

Процеси використання людського капіталу, які відбуваються в соціально-трудовій сфері, нині характеризуються досить складними і суперечливими тенденціями, що передусім пов’язані 3 дискримінацією окремих категорій населення на ринку праці, низьким рівнем оплати праці в цілому по економіці, фактичною відсутністю соціальних ліфтів для більшості працівників, кар'єрним просуванням не за здібностями, а за зв'язками, асиметріями в соціально-трудовій сфері, які сприяють зростанню непродуктивних форм людського капіталу та ін. Варто відзначити також, що нині з поширенням інформаційних технологій відбуваються суттєві зміни в соціально-трудовій сфері. Мова йде передусім про визначені фахівцями Всесвітнього економічного форуму тенденції в сфері праці на 2018-2022 pp. [10; 11], які пов'язані з поширенням інформаційних технологій: 
1. драйверами змін нині є чотири технологічні досягнення: повсюдний високошвидкісний мобільний Інтернет, штучний інтелект, широке застосування великих аналітичних даних і «хмарні» технології;

2. прискорене впровадження технологій, роботизація та автоматизація. Розширення частки машин у робочих задачах особливо відзначається у прийнятті рішень, адмініструванні, пошуку інформації; зміна географії виробничих, розподільних та цільових ланцюгів;

3. трансформація зайнятості, зростання попиту на професії, які передбачають посилене використання технологій;

4. швидке застарівання навичок, що зумовлює потребу в постійному підвищенні кваліфікації.

Фіктивізаційні процеси на етапі збереження людського капіталу передусім обумовлені асиметріями у пенсійному законодавстві, значною диференціацією між розміром отримуваних пенсій; дискримінацією за віком на вітчизняному ринку праці та ін. Нижчий рівень заробітної плати людей старшого віку як наслідок досить поширеної дискримінації за віком в Україні, фактично унеможливлює отримання людьми старшого віку якісних медичних послуг, не забезпечує на достатньому рівні фінансові можливості щодо підтримання здоров'я в належному стані та інвестування коштів в його покращення. Фіктивізації людського капіталу також сприяє низька доступність освіти для населення старших вікових груп, а також те, що в Україні немає культури навчання впродовж життя та ін. Деякі проблеми в цій царині, зокрема залучення до трудової діяльності населення пенсійного віку, могла би вирішити активізація діяльності соціальних підприємств, важливою умовою якої є державна підтримка, популяризація ідей соціального підприємництва та спрощення юридичних питань реєстрації та оподаткування діяльності соціальних підприємств.

\section{ВИСНОВКИ}

Формування непродуктивних форм людського капіталу, передусім його фіктивної складової відбувається нині досить швидкими темпами, що пов'язано з багатьма як зовнішніми чинниками, так і системними недоліками сучасної економічної системи та наявними асиметріями ринку праці. Визначені чинники фіктивізації людського капіталу на всіх етапах його відтворення є основою для оцінювання масштабів цього явища в Україні, розробки адекватних напрямів мінімізації негативного впливу фіктивізаційних процесів на національну економіку. Фіктивізаційні процеси в освітній сфері нині є предметом жвавого обговорення багатьох науковців та практиків, однак значну складність зумовлює недостатня термінологічна ідентифікація цього явища, що ускладнює процеси діалогу науковців та практиків. Крім того, це явище потребує грунтовного опису, який може слугувати в подальшому основою для визначення адекватної системи соціально-економічних заходів зі зниження негативного впливу фіктивізаційних процесів на різні аспекти суспільного життя.

\section{НАПРЯМИ ПОДАЛЬШИХ ДОСЛІАЖЕНЬ}

В сучасних умовах, актуальним також є дослідження окремих чинників фіктивізації людського капіталу, які найбільше впливають на фіктивізаційні процеси в сучасних умовах (міграційні процеси, плагіат, зниження фінансування установ НАН і МОН, i, відповідно, скорочення чисельності науковців; низький рівень академічної доброчесності, етики цитування та публікації наукових праць; кризові явища в економіці України; недостатні можливості продуктивного використання наявного трудового потенціалу та ін.).

\section{СПИСОК ЛІТЕРАТУРИ}

1. Brintseva, O. G. (2016). Фіктивний людський капітал: концептуальні підходи та особливості оцінювання [Fiktyvnyi liudskyi kapital: kontseptualni pidkhody ta osoblyvosti otsiniuvannia]. Bulletin of Taras Shevchenko national university of Kyiv. Economics, 4(181), 29-32. http://dx.doi.org/10.17721/1728-2667.2016/181-4/5

2. Grishnova, O. A., \& Brintseva, O. G. (2015). Fictitious human capital: essence, characteristics, formation factors. Demography and social 
economy, 1(23), 90-101. https://doi.org/10.15407/dse2015.01.090

3. Hrishnova, O. A., Mishchuk, H. Yu., \& Oliinyk, O. O. (2014). Соціальна відповідальність у трудових відносинах: теорія, практика, регулювання ризиків [Sotsialna vidpovidalnist u trudovykh vidnosynakh: teoriia, praktyka, rehuliuvannia ryzykiv] (216 p.). Rivne: NUVHP. Retrieved from https://cuu.su/iR4/

4. Kolyadin, A. P. (2012). Фиктивный компонент человеческого капитала как системный феномен экономики знаний [Fiktivnyiy komponent chelovecheskogo kapitala kak sistemnyiy fenomen ekonomiki znaniy] (Extended abstract of Doctor's thesis). Saratov: SGSEU.

5. Lachyna, I. (2013). ДДТУ, КНТУ, і не тільки: чи багато «мертвих душ» в українських вишах? [DDTU, KNTU, i ne tilky: chy bahato «mertvykh dush» v ukrainskykh vyshakh?]. Khai Vei. Retrieved from http://h.ua/story/384724/\#ixzz4YI92hNo8

6. Ministerstvo okhorony zdorovia Ukrainy (2017). Медична реформа у 2017 році відбуватиметься поетапно [Medychna reforma u 2017 rotsi vidbuvatymetsia poetapno]. Retrieved from http://www.moz.gov.ua/ua/portal/pre_20170104_a.html

7. Nosyk, O. M. (2015). Unemployed human capital in Ukraine: the sense and consequences. Economic theory and law, 3(22), 25-35. Retrieved from http://econtlaw.nlu.edu.ua/wp-content/uploads/2015/12/3-25-35.pdf

8. Poliakov, A. А. (2010). Проблемы инвестирования в человеческий капитал в современной экономике России [Problemyi investirovaniya $v$ chelovecheskiy kapital v sovremennoy ekonomike Rossii] (Extended abstract of Doctor's thesis). Moscow: GUU

9. Shevtsova, N. (2016). Потенціал академічної мобільності професорсько-викладацького складу ВНЗ як фактор зміцнення людського капіталу в контексті інноваційного розвитку вищої освіти в Україні [Potentsial akademichnoi mobilnosti profesorskovykladatskoho skladu VNZ yak faktor zmitsnennia liudskoho kapitalu v konteksti innovatsiinoho rozvytku vyshchoi osvity v Ukraini]. Pedagogical sciences: theory, history, innovative technologies, 3(57), 479-490. Retrieved from http://repository.sspu.sumy.ua/bitstream/123456789/1230/1/Potentsial\%20akademichnoi\%20mobilnosti.pdf

10. World Economic Forum (2016). The future of jobs. Employment, skills and workforce strategy for the fourth industrial revolution: global challenge insight report. Retrieved from http://www3.weforum.org/docs/WEF_Future_of_Jobs.pdf

11. World Economic Forum (2018). The future of jobs report 2018. Insight report. Retrieved from http://www3.weforum.org/docs/WEF_Future_of_Jobs_2018.pdf 